Phinisi Integration Review
Vol. 2, No.1, Februari 2019 Hal 137-145
Website: http://ojs.unm.ac.id/pir

\title{
Persepsi Masyarakat Tentang Simbol Karaeng Di Desa Maero Kecamatan Bontoramba Kabupaten Jeneponto
}

\author{
Zulfiana Abubakar ${ }^{(1)}$, \\ Program Pascasarjana Jurusan Ilmu Pengetahuan Sosial Universitas Negeri Makassar \\ email: zulfiana002@gmail.com
}

\begin{abstract}
Abstrak. Tujuan penelitian penelitian ini adalah persepsi masyarakat memaknai simbol karaeng di Desa Maero Kecamatan Bontoramba Kabupaten Jeneponto. Dan dampak simbol karaeng bagi masyarakat Jeneponto di Desa Maero Kecamatan Bontoramba Kabupaten Jeneponto. Penelitian ini adalah penelitian mengunakan kualitatif deskriptif. Metode pengumpulan data melalui observasi, wawancara, dan dokumentasi serta analisi data yang dilakukan reduksi data, display data, dan verifikasi data. Hasil penelitian, menunjukan bahwa ada dua temuan dalam penelitian ini. (1) Persepsi masyarakat memaknai simbol karaeng yakni Persepsi masyarakat cukup bagus dalam menilai orang yang menyandang karaeng dapat dilihat dari: perasaan, pengalaman dan kemampuan berfikir. Selanjutnya, pada simbol karaeng dalam kebudayaan di Jeneponto, terdiri atas dua bagian yakni verbal dan non-verbal. Secara verbal dapat dikelompokkan kedalam dua kategori utama, yaitu karaeng sebagai gelar bangsawan dan karaeng sebagai sapaan. Secara non-verbal dapat dilihat nampak dari atributnya,.(2) Dampak simbol Karaeng terjadi dampak yang positif dan negatif, dapat dilihat dari indikator pola hubungan sosial sangat bagus seperti: kedudukan sosial, proses sosial dan keadaan sosial disini banyaknya interaksi masyarakat sehingga terjadi hubungan kerjasama yang baik antara orang karaeng dan yang bukan karaeng. Selanjutnya, pada indikator stratifikasi sosial kurang bagus karena terjadi dampak yang negatif sehingga munculnya persaingan atau konflik yang terjadi dalam masyarakat dapat dilihat dari: konsep kelas/kelompok status dan kekuasaan.
\end{abstract}

Kata Kunci: Simbol Karaeng; Pola Hubungan Sosial.

Abstract. The study aims at discovering the public perception in interpreting on the symbol of Karaeng in Maero village of Bontoramba subdistrict in Jeneponto district. And the impact of the symbol of Karaeng for the people og Jeneponto in Maero village of Bontoramba subdistrict in Jeneponto district.

The study was descriptive qualitative research. Data were collected by employing observation, interviews, and documentation methods. Data were as analyzed by conducting, data display, and data verification.

The results of the stud, there are two findings revealed in this study: (1) the public perception in interpreting the symbol of Karaeng is fairly good which can be seen from the feelings, experience, and thingking ability. Next, the symbol of Karaeng in culture in Jeneponto consists of two parts, namely verbal and non-verbal. Verbally, it can be categorized in two main categories, namely Karaeng as noblemen title and Karaeng as greetings. Non-verbally, it can be seen from the attribute. (2) the impact of the symbol of Karaeng gives positive and negative impacts based on the indicator of social reation pattern which is very good such as social position, social process, and social condition. Lots of people interaction builds good mutual partnership between the Karaeng and the 
people of non-Karaeng. Next, the indicator of social stratification is poor because there are negative impacts which arise competition or confict in the community. It can be seen from the concept of class/group status and power.

Keywords: The Symbol of Karaeng; Social Relation Pattern

Ini adalah artikel dengan akses terbuka dibawah licenci CC BY-NC-4.0 (https://creativecommons.org/licenses/by-nc/4.0/).

\section{PENDAHULUAN}

Interaksi masyarakat dalam stratifikasi sosial biasanya dianggap penting dan bahkan sangat penting untuk digunakan dalam mengidentifikasikan latar belakang pandangan hidup, watak, sifat dari suatu masyarakat. Salah satu aspek yang sangat ditekankan khususnya di kalangan bangsawan dalam praktik sosial seharihari adalah sopan-santun dan cara bertutur kata.

Secara etimologi kata simbol berasal dari kata yunani "simbolon" yang berarti tanda pengenal, lencana atau semboyan. Konsep simbol merupakan sebuah pendekatan yang relatif khusus pada ilmu dari kehidupan manusia dan tingkah laku manusia. Dalam persfektif ini dikenal sosiolog George Herbert Mead inti pandangan simbol adalah individu, bahwa individu merupakan hal yang paling inti dalam konsep sosiologi. (Soekanto, 2006:44)

Simbol (lambang) merupakan media yang digunakan oleh seseorang untuk menyampaikan pikiran atau perasaannya kepada orang lain. Simbol dalam persfektif ini didefinisikan sebagai objek sosial yang digunakan untuk merepresentasikan apa pun yang disepakati untuk direpresentasikan. Dengan demikian simbol, merupakan media primer dalam proses komunikasi dapat berupa bahasa, isyarat, gambar, warna dan lain sebagainya. (Umiarso dalam Setiadi, 2006:187).

Manusia mempelajari simbol dan makna di dalam interaksi sosial. Manusia menanggapi tanda-tanda dengan tanpa berpikir. Sebaliknya mereka menanggapi simbol dengan cara berpikir. Tanda-tanda mempunyai artinya sendiri (misalnya, gerak isyarat anjing yang marah atau air bagi seseorang yang hampir mati kehausan). „"simbol adalah objek sosial yang dipakai untuk mempresentasikan (atau menggantikan) apa pun yang disetujui orang yang akan mereka representasikan ${ }^{\text {eee }}$ (Charon dalam Setiadi, 2006:147)
Menurut Sunarto dalam Soekanto (2006:46), menekankan bahwa rangkaian tanggapan kita terhadap suatu objek tergantung pada lingkungan sosial dan budaya tempat kita menjalani kehidupan sehari-hari kita. Jika orang asing dari kebudayaan yang tidak mengenal karaeng berjumpa dengan kebudayaan kita, maka mereka sukar mengetahui bahwa objek yang bernama karaengini adalah simbol. Seseorang harus mempelajari makna-makna itu melalui komunikasi dengan orang lain, kita harus memaknai suatu simbol.

Sebagai tambahan atas kegunaan umum diatas, simbol pada umumnya dan pada khususnya, mempunyai sejumlah fungsi khusus bagi aktor. Pertama simbol memungkinkan orang menghadapi dunia material dan dunia sosial dengan memungkinkan mereka untuk mengatakan, menggolongkan dan mengingat objek yang mereka jumpai. Kedua, simbol meningkatkan kemampuan manusia untuk memahami lingkungan. ketiga, simbol meningkatkan kemampuan untuk berpikir (Ritzer, 2008:176).

Dalam artikel berjudul "Makna Kekaraengan" tulisan Rezky (2017:35) "Karaeng" adalah nama jabatan pemerintahan pada masa "Kekaraengan" adalah bentuk pemerintahan kerajaan di bumi Turatea. Gelar Karaeng melengkapinama seorang bangsawan, karaeng memiliki arti tersendiri di mata masyarakat daerah Jeneponto. Bagi masyarakat yang menyandang gelar Karaeng berarti dia adalah seorang bangsawan dengan budi pekerti yang luhur dan ketaatan beribadah. Sebagian besar masyarakat menaruh kepercayaan kepadanya untukdijadikan sebagai seorang pemimpin. Begitu juga yang ada di desa Maero Kecamatan Bontoramba Kabupaten Jeneponto, dahulu pada zaman keKaraengan pemerintahnya adalah seorang keturunan bangsawan.

Dalam artikel berjudul "Simbol Karaeng bagi Masyarakat Jeneponto " tulisan Mirnawati 


\section{Zulfiana Abubakar. Persepsi Masyarakat Tentang Simbol Karaeng Di Desa Maero Kecamatan Bontoramba Kabupaten Jeneponto}

(2017:22) menyebutkan bahwa yang gelar karaeng sebuah simbol. Di mana karaeng sebagai gelar yang didapatkan gelar kebangsawanan, dan karaeng sebagai sapaan,

Dampak dari simbol/gelar karaeng dalam masyarakat Jeneponto yang dalam penggunaannya mengalami pergeseran tidak lain dipengaruhi oleh tata krama dalam berkomunikasi sebagai sebuah nilai-nilai adat istiadat masyarakat. Dalam hal ini, konteks karaeng sebagai sebutan atau gelar yang sebelumnya diperuntukkan bagi orang-orang yang dihormati atau dituakan, dan sejalan dengan itu bahwa tidak cukup kuatnya sistem kebudayaan dalam memberikan batasan batasan penggunaan gelar karaeng dalam kehidupan sosial, sehingga masyarakat menggunakan sebutan karaeng tersebut untuk menyapa atau memanggil masyarakat biasa sebagai sapaan yang memiliki nilai sopan atau segan kepada mereka.

Dari hasil survey dan pengamatan sementara, pada masyarakat Desa Maero Kecamatan Bontoramba Kabupaten Jeneponto, Lama kelamaan pemakai gelar "Karaeng" semakin bertambah, karena orang berlombalomba menyatakan dirinya menjadi karaeng sekalipun tidak memenuhi syarat secara adat melainkan karaeng sebagai sapaan, di mana orang yang bergelar "karaeng" mendapatkan perlakuan atau kedudukan yang istimewa di dalam masyarakat, akhirnya gelar "karaeng" kini telah menjadi ajang kesombongan, misalnya: apabila kita ketemu atau berpapasan dengan yang lebih tua biasanya kita sapa dengan kata karaeng karena itu menandakan sopan santun terhadapnya tetapi kalau tidak menyapanya dengan kata karaeng kita biasanya dinilai buruk dalam masyarakat, misalnya tidak sopan, tidak hormat kepada yang lebih tua.

Karaeng yang dahulu biasanya berdampak pada pola hubungan sosialnya, orang yang menyandang gelar karaeng suatu keturunan orang berkuasa sebagai simbol karaeng yang sangat dihormati oleh masyarakat, mereka juga sangat dilindungi dalam setiap gerak-gerik dan tindakan dalam hubungan sosial mendapat pengawasan yang sangat ketat bahkan orang begitu malu dan hormat jika harus bertemu atau berpapasan dengan orang yang menyandang karaeng atau garis keturunan karaeng.

Persepsi anak muda zaman sekarang tentang karaeng, tidak dapat memahami makna karaeng itu melainkan hanya mengenalnya dengan karaeng sebagai sapaan saja. Menyapa dengan sebutan karaeng berarti kita dinilai sopan, atau menghormati yang lebih tua, kadang menyapa dengan sebutan karaeng dapat dilihat dengan strata sosial misalnya dari segi pendidikan, pangkat, jabatan, haji atau kedudukan sosial dalam pemerintahan.

Kalau dulu, orang tua pasti akan mengkhawatirkan perilaku sosial anaknya dimata masyarakat, jangan sampai mendapatkan cela dan gunjingan dari masyarakat, apalagi sampai masyarakat mengetahui bahwa yang bersangkutan keturunan "karaeng". Sekarang zaman sudah berubah, adat sudah terlupakan seperti sapaan, orang yang berpendidikan sarjana dan mempunyai banyak harta kekayaan dapat pula tarakui atau mengakui dirinya sebagai keturunan bangsawan atau sebagai sapaan karaeng.

Dampak simbol Karaeng bagi masyarakat Jeneponto ini akan berimplikasi pada lingkungan tersebut misalnya dipengaruhi pola hubungan sosial, serta stratifikasi sosial serta berlomba-lomba menyatakan dirinya sebagai karaeng karena orang yang menyandang karaeng akan mendapatkan perlakuan yang istimewa di dalam masyarakat. Berkenaan dengan hal diatas menarik minat penulis untuk mengadakan penelitian dengan judul "Dampak Simbol Karaeng Bagi Masyarakat Di Desa Maero Kecamatan Bontoramba Kabupaten Jeneponto"

\section{A. Simbol Karaeng}

Bagi masyarakat memaknai karaeng sebagai simbol, mereka melihat bahwa individu adalah objek yang bisa secara langsung ditelaah dan dianalisis melalui interaksiknya dengan individu lain. Dalam kaitan dengan penelitian ini, simbol karaeng merujuk pada teori insteraksionalisme simbolik dalam pola hubungan masyarakat.

George Herbert Mead dalam (Ritzer, 2008:293) Interaksionalisme simbolik memusatkan perhatian terutama pada dampak dari makna dan simbol terhadap tindakan dan interaksi manusia. Dalam proses interaksi sosial, manusia secara simbolik mengomunikasikan arti terhadap orang lain yang terlibat. Orang lain menafsirkan simbol komunikasi itu dan mengorientasikan tindakan balasan mereka berdasarkan penafsiran mereka. Dengan kata lain, dalam interaksi sosial, para aktor teribat dalam proses saling mempengaruhi 
Teori interaksionalisme simbolik membayangkan bahasa sebagai sistem simbol yang sangat luas. Kata-kata adalah simbol karena digunakan untuk menggantikan sesuatu yang lain. kata-kata membuat seluruh symbol yang lain menjadi tepat. Tindakan, objek, dan kata-kata lain eksis dan hanya mempunyai makna karena telah dan dapat dideskripsikan melalui penggunaan kata-kata. Simbol adalah aspek penting yang memungkinkan orang bertindak menurut cara-cara yang khas dilakukan manusia. Karena simbol, manusia "tidak memberikan respon secara pasif terhadap realitas yang memaksakan dirinya sendiri, tetapi secara aktif menciptakan dan mencipta ulang dunia tempat mereka berperan. (Charon, dalam Setiadi, 2006:169).

George Herbert Mead dalam Teori Interaksi Simbolis (Symbolic Interaction Theory). menyarankan agar aspek internal juga dikaji untuk bisa memahami perilaku sosial, namun hal tersebut bukanlah merupakan minat khususnya. Justru dia lebih tertarik pada interaksi, dimana hubungan diantara gerakisyarat (gesture) tertentu dan maknanya, mempengaruhi pikiran pihak-pihak yang sedang berinteraksi. Dalam terminologi Mead, gerakisyarat yang maknanya diberi bersama oleh semua pihak yang terlibat dalam interaksi adalah merupakan "satu bentuk simbol yang mempunyai arti penting" (a significant symbol). Kata-kata/suara lainnya, gerakan-gerakan fisik, Atribut, kesemuanya merupakan simbol yang bermakna.

\section{B. Persepsi Masyarakat}

Persepsi adalah suatu proses yang didahului oleh penginderaan. Penginderaan merupakan suatu proses di terimanya stimulus oleh individu melalui alat penerima yaitu alat indera. Pada umumnya stimulus tersebut diteruskan oleh saraf ke otak melalui pusat susunan saraf dan kemudian proses selanjutnya merupakan proses persepsi. Stimulus diterima oleh alat indera, kemudian melalui proses persepsi sesuatu yang diterima indera tersebut menjadi sesuatu yang berarti setelah diorganisasikan dan diinterpretasikan (Soekanto, 2006:153).

Walgito dalam Soekanto (2006:159) mengemukakan melalui persepsi individu dapat menyadari, dapat mengerti tentang keadaan diri individu yang bersangkutan. Persepsi itu merupakan aktivitas yang integrateed, maka seluruh apa yang ada dalam diri individu seperti perasaan, pengalaman, kemampuan berpikir, dan aspek-aspek lain yang ada dalam diri individu masyarakat akan ikut berperan dalam persepsi tersebut.

\section{Pola Hubungan Sosial}

Bentuk umum pola hubungan sosial adalah interaksi sosial karena interaksi sosial merupakan syarat utama terjadinya aktivitasaktivitas sosial. Bentuk lain proses sosial hanya merupakan bentuk-bentuk khusus dari interaksi sosial. Individu akan saling berinteraksi dalam hal memenuhi kebutuhannya serta menghasilkan pergaulan dalam kelompok sosial dalam masyakat. Seperti halnya dengan interaksi karaeng dengan orang biasa dan interaksi sesama karaeng.

Dari dampak adanya gelar karaeng ini adalah pola hubungan sosial karena interaksi sosial Individu akan saling berinteraksi dalam hal memenuhi kebutuhannya serta menghasilkan pergaulan dalam kelompok sosial dalam masyarakat.

Soekanto (2006:57) mengatakan bahwa interaksi sosial tidak akan terjadi apabila manusia mengadakan hubungan yang langsung dengan sesuatu yang sama sekali tidak berpengaruh terhadap sistem sarafnya, sebagai akibat hubungan.

\section{Staratifikasi Sosial}

Stratifikasi berperan penting karena mengakibatkan masyarakat dapat mengatasi keterbatasan-keterbatasan mereka. Jika tiap orang diperlakukan sama dan mempunyai kesamaan derajat, maka peran kepemimpinan yang diperlukan masyarakat untuk mengatasi tantangan dan permasalahan dalam kehidupan sosial tidak terjadi.

Adanya stratifikasi, maka individu akan melakukan peran kepemimpinan. Sebab dengan melakukannya ia akan mendapat ganjaran berupa hak istimewa dan prestise. Dengan demikian stratifikasi menjadi alat yang diperlukan untuk memusatkan aktivitasnya dengan tujuan memecahkan masalah dan menghadapi tantangan. Makin besar masalah dan tantangan yang dihadapi, makin besar kebutuhan akan stratifikasi (Ratna, 2016:15).

Menurut Teori Max Weber, konsep stratifikasi sosial dalam pandangannya adalah multidimensional. Perhatian utama weber dalam studi stratifikasi sosial tercermin dalam konsep kelas/kelompok status, dan kekuasaan. Stratifikasi terbentuk karena adanya fenomena ketimpangan/ kesenjangan distribusi dan 
kekuasaan. Weber membangun teori tiga dimensi dan konsep kesempatan hidup (life chanes) dalam menjelaskan stratifikasi sosial. Kesempatan hidup dapat digambarkan dalam kesempatan memperoleh pendidikan, kesehatan, perumahan, dan sebagainya (Ratna,2016:7).

Adapun orang yang memperoleh kekuasaan dari para pengikutnya bisa dikatakan ia memiliki kekuasaan pribadi. Meski begitu, ada juga orang yang mempunyai kedua-duanya, yaitu kekuasaan jabatan dan kekuasaan pribadi sekaligus.

\section{METODE PENELITIAN}

Penelitian ini adalah jenis penelitian kualitatif deskriptif, yaitu penelitian yang dilakukan untuk memperoleh gambaran situasi dan kejadian atau memahami fenomena tentang apa yang dialami oleh subyek penelitian misalnya, perilaku, persepsi, motivasi, tindakan dan lain-lain secara holistik dan dengan cara deskripsi dalam bentuk kata-kata dan bahasa, pada suatu konteks khusus yang alamiah dan dengan memanfaatkan berbagai metode alamiah.

Lokasi penelitian ini dilaksanakan di Desa Maero Kecamatan Bontoramba Kabupaten Jeneponto. Dalam penelitian ini pemilihan lokasi dilakukan secara purposive yaitu ditetapkan secara sengaja oleh peneliti berdasarkan atas kriteria atau pertimbangan tertentu dalam penelitian ini. Alasan mengapa mengambil lokasi tersebut karena peneliti sebagai salah satu masyarakat Jeneponto dan lebih memahami permasalahan yang ada tentang menyangkut Karaeng.

Dalam penelitian ini teknik yang di pakai dalam mengumpulkan data adalah teknik observasi, wawancara dan dokumentasi. Ketiga teknik tersebut dijelaskan sebagai berikut.

\section{a. Obesrvasi}

Observasi atau pengamatan adalah proses pengambilan data dalam penelitian ini di mana peneliti atau pengamat melihat situasi penelitian. Teknik ini digunakan untuk mengamati dari dekat dalam upaya mencari dan menggali data melalui pengamatan secara langsung dan mendalam terhadap makna simbol karaeng.

\section{b. Wawancara}

Wawancara adalah mengumpulkan datadata dan informasi yang dibutuhkan dengan cara melakukan tanya jawab dengan pihak-pihak atau orang-orang yang di anggap memiliki kompeten untuk dimintai pendapat, ide-ide, dan berbagai informasi yang di butuhkan. Dalam ini mengunakan wawancara secara terstruktur yaitu wawancara yang bersifat tersusun dan sistematis untuk di tanyakan kepada informan dan wawancara secara tidak terstruktur yaitu wawancara yang sifatanya bebasa kepada informan dalam penelitian tersebut.

\section{c. Dokumentasi}

Dokumentasi adalah cara pengumpulan data yang dilakukan dengan mengupulkan datadata yang berupa dokumen baik tertulis maupun hasil gambar. Peneliti mengambil dari data-data yang relevan berkaitan dengan penelitian serta pengambilan gambar pada saat observasi, wawancara, maupun penggunaan simbol masyarakat Jeneponto khususnya di Desa Maero.

\section{HASIL DAN PEMBAHASAN}

Berdasarkan hasil penelitian yang telah diuraikan, maka pembahasan hasil penelitian untuk mengetahui lebih lanjut mengenai persepsi masyarakat tentang simbol karaeng dan dampak simbol karaeng

\section{Persepsi masyarakat tentang simbol karaeng di Desa Maero Kecamatan Bontoramba Kabupaten Jeneponto}

Berdasarkan hasil penelitian yang dilaksanakan melalui wawancara, observasi dan dokumentasi maka hasil penelitian dari persepsi masyarakat tentang simbol karaeng yaitu diuraikan secara rinci dalam pembahasan.

.Dari hasil penelitian mengungkap bahwa dengan kata karaeng biasa dipakai oleh masyarakat Maero untuk menyapa orang-orang yang dihormatinya. Sehingga masyarakat biasa bangga dan senang jika dipakai untuk menyapa orang yang bangsawan dan juga orang yang bukan bangsawan dengan karaeng tergantung dari orang yang menyapanya karena memandang orang tersebut patut dihormati.

Dalam Buku Monografi Kebudayaan Makassar di Sulawesi Selatan yaitu mengkaji tentang Gelar Karaeng dalam masyarakat suku makassar, bahwasanya gelar (nama) Karaeng mempunyai prestasi atau keunggulan pribadi 
yang menempatkannya pada posisi yang lebih tinggi. Prestasi atau keunggulan pribadi tersebut memiliki istilah-istilah tersendiri dalam kebudayaan suku Makassar, yaitu: kacaraddekang, kabaraniang, dan kakalumannyangngang

a. Kacaraddekang adalah seseorang yang memiliki kepandaian dan kebijaksanaan, sebuah prestasi yang akan menempati kedudukan sosial yang terpandang dalam masyarakat, seperti menjadi pemuka agama (ulama) yang disebut panrita, anrong guru, atau dalam berbagai lapangan pendidikan keterampilan baik fisik maupun mental, fungsi sosial yang dipandang dalam kehidupan dunia atau akhirat.

b. Kabaraniang adalah seseorang yang memiliki keberanian yang menonjol dalam arti kemampuan fisik dan mental, dalam mengerjakan suatu pekerjaan yang mempunyai resiko berat seperti tewas, binasa atau terbuang dari kumpulan. Orang-orang yang memiliki keunggulan seperti ini biasanya dapat tampil sebagai punggawa bunduk (pemimpin pasukan dalam peperangan), pallapa" barambang (pelindung orangorang yang memerlukan perlindungan), punggawa paella" (pimpinan perampok atau bajak laut), dan berbagai pekerjaan lainnya yang memerlukan keberanian. Keunggulan ini apabila telah mendapat pengakuan sosial, maka iapun akan mendapat pengikut, berpengaruh, dan dihormati.

c. Kakalumannyangngang adalah seseorang yang karena keunggulan pribadinya dalam berusaha, sehingga dapat mengumpulkan kekayaan untuk memperkerjakan banyak orang dan menghidupkannya, maka keadaan yang dicapainya itu mengangkat ke jenjang kehidupan sosial yang terpandang.

Simbol karaeng merupakan nama julukan atau penghargaan terhadap seseorang yang memiliki ciri khas atau kelebihan (keahlian/prestasi), dalam kehidupan sosial masyarakat suku Makassar.

Pertahanan makna sebuah simbol dalam masyarakat yang secara signifikan mengalami pergeseran dari masa kemasa yang dimana perubahan ini mengakibatkan makna simbol mengalami perluasan makna. makna simbol gelar karaeng secara verbal dan non verbal, dan lebih melihat bagaimana masyarakat mengalami perubahan di dalamnya sebagai salah satu kekuatan yang dapat digunakan untuk membagun kepercayaan masyarakat sekaligus membangun relasi kepada masyarakat dan memanfaatkan untuk memperjuangkan keberadaan simbol

karaeng dalam masyarakat.

Makna dan sesuatu berasal dari caracara orang lain bertindak terhadap suatu individu dalam kaitannya dengan sesuatu tertentu. Hasil temuan dari lapangan ditemukan secara verbal dan non verbal yaitu secara verbal masyarakat memaknai simbol karaeng dengan 2 gelar yaitu karaeng sebagai gelar kebangsawanan, dan sebagai sapaan penghormatan sedangkan non verbal dapat dilihat nampak dari atributnya, antara lain pada namanya memakai kata karaeng atau disingkat "kr", Penutup atap bagian depan rumahnya biasanya teridiri dari tiga, empat, lima atau tujuh lapis/tingkat (reka bentuk rumah dapat dilihat dihalaman lampiran). Mengadakan barzanji atau korongtigi selama minimal 3 malam berturutturut saat melakukan hajatan perkawinan atau sunatan yang berbeda dari adat lain, dan sebagainya.

. Tidak hanya itu dari teori yang di kemukakan oleh Meed yaitu, Kata-kata dan suaralainnya, gerakan-gerakan fisik, dan atribut, kesemuannya merupakan simbol yang bermakna. (George Herbert Meed) Mengambarkan keberdaan karaeng yang dapat dilihat nampak dari atributnya.

\section{Dampak Simbol Karaeng di Desa Maero Kecamatan Bontoramba Kabupaten Jeneponto}

Hasil penelitian dijelaskan bahwa dampak simbol karaeng terjadi dampak positif dan negatif. Pada dampak positifnya terjadi pada indikator pola hubungan sosial dan dampak negatif terjadi pada stratifikasi sosial. Dampak simbol karaeng ini dapat memenuhi indikator dalam penelitian ini diuraikan sebagai berikut:

a. Pola hubungan sosial

Pada indikator pola hubungan sosial cukup bagus seperti dapat dilihat dari: kedudukan sosial, proses sosial dan keadaan sosial.

Bentuk umum pola hubungan sosial adalah interaksi sosial karena interaksi sosial merupakan syarat utama terjadinya aktivitasaktivitas sosial. Bentuk lain proses sosial hanya merupakan bentuk-bentuk khusus dari interaksi sosial. Individu akan saling berinteraksi dalam hal memenuhi kebutuhannya serta menghasilkan pergaulan dalam kelompok sosial dalam 


\section{Zulfiana Abubakar. Persepsi Masyarakat Tentang Simbol Karaeng Di Desa Maero Kecamatan Bontoramba Kabupaten Jeneponto}

masyakat. Seperti halnya dengan interaksi karaeng dengan orang biasa dan interaksi sesama karaeng.

Dari dampak adanya gelar karaeng ini adalah pola hubungan sosial karena interaksi sosial Individu akan saling berinteraksi dalam hal memenuhi kebutuhannya serta menghasilkan pergaulan dalam kelompok sosial dalam masyarakat.

George Herbert Mead dalam (Ritzer,2008: 295) dalam deskripsinya mengungkapkan bahwa proses pengambilan peran menduduki tempat penting. Interaksi berarti bahwa para peserta masing-masing memindahkan diri mereka secara mental kedalam posisi orang lain. Dengan berbuat demikian, mereka mencari arti maksud yang oleh pihak lain diberikan kepada aksinya sehingga komunikasi dan interaksi dimungkinkan.

Terdapat beberapa pola interaksi yang dipengaruhi dalam masyarkat di desa Maero, antara lain:

1) Kedudukan sosial (status) dan peranannya

Interaksi ini dipengaruhi oleh pikiran dan perasaan yang mengakibatkan munculnya beberapa frekuensi interaksi yang terjadi dalam masyarakat di desa Maero, seperti jarak sosial, perasaan simpati yang sangat dipengaruhi oleh status dan peranan sosial, semakin besar perbedaan status sosial semakin besar pula jarak sosialnya.

2) Proses sosial masyarakat

Proses sosial masyarakat dapat dilihat dari hubungan sosialnya, Dalam diri tiap-tiap orang terdapat suatu lapisan bawah sadar terdiri dari naluri-naluri dan sepadu dengan orangorang lain.

Dari observasi dan hasil penelitian penulis, masyarakat Desa Maero terkenal ramah, tekun dan rajin bekerja. Dalam keseharian dan ketika ada hajatan, mereka saling membantu, budaya sipakatau, sirie napacce antar warga masih terpelihara dengn baik. Budaya gotong royong yang masih dapat disaksikan sampai dasawarsa ini adalah budaya saling membantu ketika ada hajatan sunatan, pernikahan ataupun acara kematian.

Perbedaan yang nyata dari pernyataan informan diatas dilihat dari status ekonomi masyarakat Maero yaitu bahwasanya orang yang bergelar karaeng memiliki ekonomi yang baik yaitu orang yang kaya sedangkan yang bukan karaeng memiliki ekonomi standar atau miskin, akan tetapi hal tersebut tidak menutup kemungkinan bahwa hubungan diantara keduanya tidak baik, justru dengan keadaan tersebut perbedaan tersebut membuat hubungan keduanya menjadi baik. Dari adanya interaksi tersebut seseorang melakukan penyesuaian, pembaruan, terjalin kerjasama, adanya persaingan, bahkan dapat munculnya suatu pertentangan dan seterusnya.

3) keadaan sosial masyarakat

Merupakan penelaahan tentang perubahan-perubahan yang terjadi di dalam fakta-fakta sosial yang saling berhubungan satu dengan yang lainnya.

Pengamatan banyak orang tentang kejadian sosiologis dari dulu hingga sekarang menimbulkan kesimpulan bahwa tidak ada sesuatu yang tetap, segalanya berubah terus menerus. Berdasarkan pengamatan seharihari di ketahui bahwa setiap masyarakat, setiap satuan kebudayaan mengalami perubahan, namun tetap mempertahankan kepribadian.

Dari hasil observasi dapat dilihat bahwa Kehidupan itu adalah suatu yang dinamis, dengan demikian setiap kehidupan akan senantiasa mengalami perubahan, dan pada konteks manusia, maka manusia pun juga akan mengalami perubahan, baik ia sebagai individu maupun masyarakat. Karena kehidupan itu dinamis, maka perubahan yang terjadi adalah suatu fenomena yang lumrah atau normal pengaruhnya bahkan bisa menjalar dan merambah kebagian belahan dunia lain dengan cepat dan efektif karena didukung oleh kemajuan komunikasi yang canggih dan modern seperti yang telah terjadi pada masa sekarang.

b. Stratifikasi Sosial

Pada indikator Stratifikasi sosial kurang bagus sebab terjadi dampak negatif bagi masyarakat seperti dapat dilihat dari: konsep kelas/kelompok status dan kekuasaan.

Dengan adanya dampak simbol karaeng yang dipengaruhi staratifikasi sosial sehinga terjadi persaingan atau konflik di dalam masyarakat Maero. Diantaranya adalah kelompok status dan kekuasaan seperti posisi dibidang pemerintahan dan kekayaan. Tidak hanya status sosial makna dari simbol gelar karaeng pun mengalami pergeseran seiring dengan berjalannya waktu.

Menurut Teori Max Weber, konsep stratifikasi sosial dalam pandangannya adalah multidimensional. Perhatian utama weber dalam 
studi stratifikasi sosial tercermin dalam konsep kelas/kelompok status, dan kekuasaan. Stratifikasi terbentuk karena adanya fenomena ketimpangan/ kesenjangan distribusi dan kekuasaan. Weber membangun teori tiga dimensi dan konsep kesempatan hidup (life chanes) dalam menjelaskan stratifikasi sosial. Kesempatan hidup dapat digambarkan dalam kesempatan memperoleh pendidikan, kesehatan, perumahan, dan sebagainya (Ratna,2016:7).

Max Weber melihat bahwa kelas berhubungan erat dengan kesempatan hidup sesorang. Masyarakat yang menduduki kelas sosial yang lebih tinggi pula dan juga dapat memperoleh akses yang lebih besar, dan sebaliknya bagi masyarakat dengan kelas sosial yang lebih rendah (Ratna, 2016:8).

Proses terbentuknya stratifikasi sosial masyarakat pada umumnya dapat dilihat dalam hubungan masyarakat yang disebabkan oleh adanya penghargaan dalam masyarakat terhadap sesuatu yaitu diantaranya kekayaan, jabatan, pendidikan dan lain-lain. Disamping itu terdapat faktor faktor yang mempengaruhi terbentuknya stratifikasi sosial dalam masyarakat, diantarnya adalah faktor kekayaan, pendidikan dan kedudukan dalam masyarakat

\section{SIMPULAN DAN SARAN}

\section{Kesimpulan}

1. Persepsi masyarakat cukup bagus dalam menilai orang yang menyandang karaeng dapat dilihat dari: perasaan, pengalaman dan kemampuan berfikir. Selanjutnya, pada simbol karaeng dalam kebudayaan di Jeneponto, terdiri atas dua bagian yakni verbal dan non-verbal. Secara verbal dapat dikelompokkan kedalam dua kategori utama, yaitu karaeng sebagai gelar bangsawan dan karaeng sebagai sapaan penghormatan. Secara non-verbal dapat dilihat nampak dari atributnya, antara lain pada namanya memakai kata karaeng atau disingkat "kr", Penutup atap bagian depan rumahnya biasanya teridiri dari tiga, empat, lima atau tujuh lapis/tingkat (reka bentuk rumah dapat dilihat dihalaman lampiran). Mengadakan barzanji atau korongtigi selama minimal 3 malam berturut-turut saat melakukan hajatan perkawinan atau sunatan yang berbeda dari adat lain, dan sebagainya.
2. Dampak simbol Karaeng terdapat dampak yang positif dan negatif, dapat dilihat dari indikator pola hubungan sosial sangat bagus seperti: kedudukan sosial, proses sosial dan keadaan sosial disini banyaknya interaksi masyarakat sehingga terjadi hubungan kerjasama yang baik antara orang karaeng dan yang bukan karaeng. Selanjutnya, pada indikator stratifikasi sosial kurang bagus karena terjadi dampak yang negatif sehingga munculnya persaingan atau konflik yang terjadi dalam masyarakat dapat dilihat dari: konsep kelas/kelompok status dan kekuasaan.

\section{Saran}

Berdasarkan hasil penelitian dan pembahasan serta kesimpulan yang telah dikemukakan, berikut ini adalah beberapa saran yang diharapkan dapat menjadi masukan dan bahan pertimbangan untuk penelitian selanjutya, adapun saran tersebut berikut ini:

1. Diharapkan masyarakat Jeneponto yang harus di pertahankan dan dijaga kearifan lokalnya dimana Desa Maero Kecamatan Bontoramba Kabupaten Jeneponto adalah lokasi yang berlatar belakang karaeng dan merupakan bagian dari kerajaan Bontoramba.Gelar karaeng merupakan sebuah simbol yang bermakna bagi masyarakat, dengan ini semoga dapat di pergunakan sebagaimana mestinya. Diharapkan agar penilaian sebagian besar masyarakat terhadap simbol karaeng sekarang ini menyadari bahwa makna karaeng mengalami pergeseran makna,perubahan sosial yang berdurasi jangka panjang dan memiliiki amplikasi yang kuat terhadap tatanan sosial.

2. Adanya dampak simbol karaeng, diharapkan kepada masyarakat agar kiranya tetap menjaga pola hubungan dalam masyarakat dengan baik meskipun terdapat beberapa perbedaan atau dilihat staratifikasi sosial sehingga tidak terjadi konflik dalam masyarakat.

\section{DAFTAR RUJUKAN}

Agussalim, A.M. 2005. Ilmu Sosial Budaya Dasar: $\quad$ Suatu Pendekatan 
Multidisplin. Makassar: Badan Penerbit Universitas Negeri Makassar

Bungin, Burhan. 2001.Penelitian Kualitatif. Jakarta; PT Raja Grafindo.

Hussein, Adnan. 2011. Mix Methodology Dalam Penelitian Komunikasi (Dilengkapi Dengan Aplikasi Metode Penelitian) Yogyakarta: Mata Padi Pressindo

Martono, Nanang. 2012. Sosiologi Perubahan Sosial. Jakarta: Rajawali Pers.

Mirnawati. 2017. Simbol Karaeng Bagi Masyarakat Jeneponto. Jurnal Ilmu Sosial Budaya, (online), Jilid 8, No 2, (https://nano.com/simbol-karaengbagi-masyarakat-jeneponto.html, Diakses 30 April 2018)

Pelras, C. (2006). Manusia Bugis, Nalar Bekerja sama dengan Forum Jakarta- Paris, EFEO, Jakarta

Ratna, I.P.I .(2016). Stratifikasi Sosial dan Mobilitas Sosial. Yayasan Pustaka Obor Indonesia

Rachmah.1984. Monografi Kebudayaan Makassar di Sulawesi Selatan. Pemerintah Daerah Tingkat I Sulawesi Selatan. Ujung Pandang

Rezky. 2017. Makna Kekaraengan. Kompasiana (online).

http;///www.dutamasyarakat.com/artik el-29).

Ritzer George, Goodman J Douglas. 2008. Teori Sosiologi Modern. Jakarta: Kencana

Setiadi M, Elly, dkk. 2006. Ilmu Sosial Budaya Dasar. Jakarta: PT Fajar Iterpratama Mandiri.

Sugiyono. 2011. Metode penelitian kuantitatif kualitatif dan R\&D. alfabeta.

Zainuddin, Andi, dkk. 2003. Tiga Ungkapan Sejarah Turatea. Makassar: Badan Arsip dan Perpustakaan Daerah Provinsi Sulawesi Selatan 